\title{
Article \\ Changes in the Stock Market of Food Industry Companies during the COVID-19 Pandemic-A Comparative Analysis of Poland and Germany
}

\author{
Elżbieta Kacperska (D) and Jakub Kraciuk *(D) \\ Institute of Economics and Finance, Warsaw University of Life Sciences, 02-787 Warsaw, Poland; \\ elzbieta_kacperska@sggw.edu.pl \\ * Correspondence: jakub_kraciuk@sggw.edu.pl
}

Citation: Kacperska, E.; Kraciuk, J. Changes in the Stock Market of Food Industry Companies during the COVID-19 Pandemic-A Comparative Analysis of Poland and Germany. Energies 2021, 14, 7886. https://doi.org/10.3390/en14237886

Academic Editors: Karolina Pawlak and Ricardo J. Bessa

Received: 30 September 2021

Accepted: 17 November 2021

Published: 24 November 2021

Publisher's Note: MDPI stays neutral with regard to jurisdictional claims in published maps and institutional affiliations.

Copyright: (c) 2021 by the authors. Licensee MDPI, Basel, Switzerland. This article is an open access article distributed under the terms and conditions of the Creative Commons Attribution (CC BY) license (https:// creativecommons.org/licenses/by/ $4.0 /)$.

\begin{abstract}
The COVID-19 pandemic had a dramatic effect on the world economy, leading to disturbances in the global agri-food system. Disrupted supply chains caused instability in the market resulting in mixed reactions among market participants. The balance in the access and availability of food was disturbed at various levels starting from local up to international. Partial lockdowns of economies affected the equilibrium on the labor market in the food sector, the level of income and food security. The aim of this study was to determine the effect of shock caused by the COVID-19 pandemic on rates of return from shares of companies in the agri-food sector listed in Poland and Germany, as well as indicate dependencies between restrictions imposed by the investigated countries and changes in the rates of return from shares as a result of the pandemic. The source of data for the analyses of the capital markets in Poland and Germany was the Thomson Reuters database. In order to determine the effect of shock caused by the coronavirus pandemic and restrictions imposed by the states on the capital market the abnormal rates of return were calculated for shares of 24 Polish and 23 German companies from the food sector. The investigated Polish companies were listed on the Warsaw Stock Exchange, while the German companies were listed on the Frankfurt Stock Exchange and other stock exchanges in Germany. Calculations were based on stock market indexes: for the Polish stock exchange it was WIG and WIG-food, while for the German capital market it was DAX and DAX Food \& Beverages. In this study the Stringency Index was also used as a tool to follow the response of the governments to the coronavirus pandemic. The results indicate that following the pandemic outbreak large reductions were observed for cumulative rates of return from shares as a consequence of the pandemic both in Poland and Germany. Abnormal cumulative rates of return for the investigated companies were comparable. Markedly greater increases in abnormal rates of return were recorded for the Polish companies of the food sector listed at the Warsaw Stock Exchange. The Stringency Index indicates that restrictions imposed by the German authorities in response to the coronavirus pandemic were slightly more radical than those introduced by the Polish government.
\end{abstract}

Keywords: food industry; sustainable development; stock market; COVID-19 pandemic; crisis; Poland; Germany

\section{Introduction}

The COVID-19 pandemic has changed and put the world at the standstill, while also having a profound impact on all aspects of human life. It has caused not only serious health problems, but also severely undermined economic, financial and food security on the global scale [1-3]. The virus, which was detected for the first time in China in December 2019 , spread to all countries worldwide. The pandemic officially declared by the World Health Organization (WHO) [1] on 11 March 2020 resulted in over 232 million confirmed infection cases, as well as over 4.75 million deaths worldwide (according to the data for 27 September 2021) [4]. In Poland the first case of coronavirus infection was detected on 4 March 2020, while by 27 September 2021 a total of over 2.9 million infection cases was 
recorded and over 75.5 thousand infected patients died [4]. The present pandemic has led not only to a global health crisis, but also the global economic crisis, caused primarily by the imposed strict quarantine regulations. In the current literature on the subject an increasing number of studies concern the effect of COVID-19 on the financial market, indicating the reactions of investors triggered by the pandemic [5-7]. Shocks observed on the financial market were characterized by variability and tended to be extended in time [8]. This may have a negative effect on the economic and financial systems of any country [9]. A dramatic increase in uncertainty and risk recorded in the financial markets affects negatively the obtained rates of return and thus the current market value of shares [10,11]. This situation is also observed on stock exchanges in Poland, i.e., the Warsaw Stock Exchange, and in Germany on the Frankfurter Wertpapierbörse. Share prices in the case of various companies undergo considerable fluctuations, with the variability in the prices differing depending on the sector or product type. The aim of this study was to determine the effect of shock caused by the coronavirus on rates of return from shares of companies in the agri-food sector in Poland and in Germany, as well as indicate dependencies between restrictions imposed by the analyzed countries and fluctuations in rates of return from shares caused by the pandemic. This publication shows a research gap in this respect. Previously the mean adjusted model was not used to calculate the rates of return caused by the supply and demand shocks. The paper provides a novel contribution to science, since it is the first empirical study concerning the effect of the COVID-19 pandemic on the stock market of agri-food sector companies in Poland compared to the German market. This article documents the impact of the coronavirus pandemic on the stock market in the agri-food sector and constitutes a point of reference to the assessment of trends in this market following the pandemic.

The study results will provide insight into what happens on the stock exchange during a pandemic, while they will also aid economic entities in making investment decisions and planning the future.

This paper is also an opportunity to initiate further research aiming at an assessment of the effect of the COVID-19 pandemic on stock markets in the agri-food sector also in other countries and worldwide, as well as suggest directions for further studies concerning consumer behavior in crisis situations.

\section{A Review of Literature}

In the history of the contemporary world economy various pandemics, epidemics and outbreaks of diseases on the international scale have been recorded several times. The most dangerous in terms of their consequences include the Spanish flu pandemic of 1918, the epidemics of the Ebola virus, HIV / AIDS, SARS and the current COVID-19 pandemic [12-16]. The extent of pandemics in the globalized world extends over national borders causing global consequences, such as high unemployment, decrease in GDP, closures and bankruptcies of enterprises, which further leads to a reduction of individual incomes and poverty. On the global scale they cause disturbances in the world markets, stock exchanges, international trade and tourism. Pandemics are also associated with high mortality rates. Experiences from the previous crises caused by such factors indicate a certain pattern of their impact on the economies [17,18], including stock exchanges [19]. The rapid spread of viruses is followed, equally rapidly, by disturbances in international production chains, downtimes and shortages of goods. Many countries, in order to counter the spread of the pandemic decide to close individual branches of the economy, not to mention the closure of national borders in 2021. These actions slow down the spread of the virus, but unfortunately also contribute to huge disturbances in economic activity. Hsieh et al. [20] indicated that during the Spanish flu pandemic 50\% world population was infected, while approx. $25 \%$ suffered from serious complications. Barro, Ursua and Weng [21] reported that mortality amounted to approx. $2 \%$ population. It is estimated that due to the Spanish flue around 40-50 million of people died. This flu, which progressed in three waves, coincided with the outbreak of WWI, while dramatically bad conditions 
in areas affected by military actions contributed to its rapid spread. Grzeszak et al. indicated that "in the economic perspective the epidemic constituted a strong supply shock on the labour market at the simultaneous slight shock for the material resources of the economy" [16]. Consequences of the epidemic included growing poverty and decreasing capital gains, at the slight effect on the stock market [22]. According to Taylor [23], waves of the pandemic in the USA had no impact on the Dow Jones Industrial Average index in the years 1918-1919 (the war had a greater effect). Barro, Ursúa and Weng [19] showed similarities between COVID-19 and the Spanish flu in order to indicate changes in the economic situation of countries, caused by the pandemic. Pandemics, which cover the entire globe, are connected with high mortality, while the external supply shock becomes a source of crisis. The Great Flu Pandemic of 1918-1920 in the opinion of the authors was probably the worst scenario of global epidemics of diseases such as COVID-19. Mortality comparable to that caused by the Spanish flu at present, in the worst-case scenario, would cause approx. 150 million deaths worldwide. Moreover, the authors stated that such a mortality rate would lead to a mean annual decrease in GDP by $6 \%$, while it would reduce private consumption levels by $8 \%$. Results of analyses also show that the pandemic of 1918-1920 was accompanied by considerable short-term reductions in real rates of return from shares and short-term Treasury bonds [21].

SARS was an epidemic originating in China, which in the years of 2002-2003 affected 29 Asian countries and spread on the international scale covering North America, South America and Europe. According to Ahmad, Krumkamp and Reintjes [24], 8096 people became ill, of which 774 died. The economic effects of this epidemic were estimated at a 0.5-1\% loss of annual GDP in the most severely affected countries: China, Hong Kong, Singapore and Taiwan [16]. The most dramatically affected branches included tourism, where the number of flights dropped by as much as $80 \%$, as well as the hospitality industry, transport and the retail sector [25]. Governments of individual countries implemented periodical closures of schools and public institutions, while quarantines, controls and restrictions in international trade were also imposed [16,24]. According to Lee and Mc Kibbin [15], the SARS epidemic caused considerable losses and high costs. According to those authors, the global cost amounted to approx. 80 billion dollars. That epidemic led to 800 deaths worldwide.

The Zaire ebolavirus causing hemorrhagic fever, commonly called the Ebola virus, is another dangerous disease characterized by a high mortality rate. Denes and Gumel [26] described it as a disease rapidly spreading through contact with blood, secretions, bodily fluids and organs of infected humans and animals. The incubation period lasts from 2 to 21 days and the disease causes high fever leading to hemorrhages and death. The mortality rate is around 25-90\%. That epidemic affected African countries: the Republic of Guinea, the Democratic Republic of the Congo, Liberia and Sierra Leone. Over the years 2013-2018 over 11 thousand people died. Another consequence was connected with the paralysis of economies. According to Sy \& Copley [27], in agriculture of many countries harvests were lower, resulting in a rapid increase in prices of agricultural products and increased inflation.

A negative effect on the economy in many countries was also observed in the case of the HIV / AIDS pandemic. It has been spreading since 1981. The data presented in a report by the Kaiser Family Foundation (KFF) from 2019 showed that 1.1 million people were infected with HIV, while over 700 thousand died since the beginning of the pandemic. This disease has a considerable effect on the labor force, particularly in less economically developed countries, where poor healthcare contributes to a rapid increase in morbidity. In countries with high levels of infections the labor force is depleted; additionally, the disease leads to overall weakness and wasting of people's organisms, increased susceptibility to disease, while at the same time reducing labor efficiency and potentially causing loss of jobs. As a result, governments incur losses due to unpaid taxes and at the same time have to cover growing healthcare costs [28]. 
The current COVID-19 pandemic has covered practically the entire globe [1]. Grzeszak et al. [16] indicated the mechanism of crisis caused by the COVID-19 pandemic. It comprises five stages:

- $\quad$ Stage 1-disruption of the supply chain from China,

- Stage 2-introduction of lockdowns in selected sectors,

- Stage 3-complete closure of the economy,

- Stage 4-gradual loosening of restrictions,

- $\quad$ Stage 5-return to the new normal.

The external shock experienced in many countries, resulting from the disruption of the supply chains from China, consequently caused a slowdown in production in many countries [29,30]. Sick leaves of workers and a lack of raw materials caused a supply shock, while the restrictions imposed by governments and initially partial and later complete lockdowns of economies further aggravated the crisis [31,32]. Complete lockdowns of economies cause a demand shock. Consumption is reduced as a result of restrictions, private investments decrease as a consequence of the deterioration of the financial situation of enterprises, as well as an evident crash in some sectors (tourism, the catering industry, transport). The economic crisis leads to a strengthening of pessimistic attitudes in the society, consumer confidence is reduced, similarly as the confidence of entrepreneurs, the situation in the financial markets deteriorates, being additionally aggravated by capital flight and potential panic $[16,31,32]$. At all the stages of the economic crisis the financial system is at risk of instability. Fluctuations of prices and an increase in risk cause increased uncertainty on the market and undermine trust in business partners. Risk aversion increases, enterprises face liquidity problems, the volume of bad loans grows, while stability of the financial sector deteriorates. The market disequilibrium leads to loss of trust and may be the basis for economic decisions. In the crisis situation decisions are made under pressure, facing uncertainty [33]. In an uncertain situation obtained information may result in irrational decisions [9]. Literature on the subject presents many theories describing the behavior of investors on the market, such as e.g., theories of the efficient market [34-36], the behavioral finance theory $[37,38]$, theories of rational expectations or the concept of black swans [39-43]. They all indicate a significant role of information, market efficiency, rationality and individual behavior of market participants and market anomalies. Available scientific literature on the subject concerning relationships between extraordinary events and share prices focuses mainly on terrorist attacks [44-47], natural disasters [48], political behavior [49] and financial crises [50,51]. On the capital market extraordinary situations frequently affect investor behavior through their influence on investor moods, which finally has an impact on share prices $[52,53]$. Studies have shown that these impulses influenced fluctuations in share prices, while the typically observed initial considerable decrease in share prices followed by the return to the previous levels progressing at varying rates [54]. Research results also indicate changes in risk, e.g., the European debt crisis of 2010 affected risk in the main European markets, particularly the German, French and British markets [55]. Stock markets in different countries react differently to the COVID-19 pandemic [56]. Min Liu, Wei-Chong Choo and Chien-Chiang Lee [57] suggest that the COVID-19 pandemic had a considerable effect on the share market. Those researchers showed that the share market in a more economically developed country initially tends to react excessively to an extreme shock. The share market in an economically undeveloped country in the beginning shows a weaker reaction, however it is the least willing to bounce back from the previous level, since it has the highest level of the abnormal cumulative rate of return even 10 days after the announcement. In turn, the share market in a more economically developed country is characterized by the fastest recovery rate, although initially it was affected the most severely. This indicated that generally a country with a greater revenue level generates a more efficient market responding faster to an extreme disease and vice versa" [57]. Chen and Siems [47] argue that even an event with the same characteristics may not necessarily produce similar effects. Other studies focused on individual sectors or branches. Among other things, analyses concerned the influence 
of airplane accidents on the share market [58], the impact of disasters on the insurance market [59] and the effect of the financial crisis on the share market [60]. Literature on the influence of crises on the share market is relatively extensive $[53,60,61]$; however, very few studies analyze the influence of public health events on share markets [62,63]. Among other things, Chen, Jang and Kim [64] investigated the long-term effect of the SARS pandemic on four main share markets in China and Asia and they found that it has a considerable effect on the financial integration of the share market. COVID-19 has a huge and lasting negative impact on the world economy $[6,65,66]$. Sobieralski [67] indicated that as a result of the COVID-19 pandemic share prices on the Chinese market dropped to historically low levels, while on the American share market four unprecedented decreases were recorded. The shown negative consequence of COVID-19 on the share market is also connected with increased problems with the prevention and control of risk [68]. Nevertheless, available body of literature also includes limited studies on the branch level concerning the effect of COVID-19 on share prices, as well as limitations within specific branches of the economy concerning the level of the economic impact of COVID-19 [69].The world crisis caused by the COVID-19 pandemic exerted an unprecedented impact on markets, causing a deep, global economic recession, increased poverty and chronic loss of food security [70]. Successive waves of the pandemic lead to imposed restrictions, aggravating the unstable situation in food security and nutrition worldwide [70].

The COVID-19 pandemic affected food security, among other things food availability or stability of supplies [71-75]. Drastically slowed down deliveries caused instability of food systems, which became unable to supply adequate amounts of goods on the market. Many workers employed in the food industry became ill, many lost their jobs due to lockdowns, many people lost their sources of income [75-78]. Changes both in the supply and demand for food were accompanied by changes in prices leading to instability of food systems [75,79]. Governments in most countries worldwide imposed numerous restrictions and safety measures aiming at the maintenance of food security and restoration of equilibrium in agricultural markets [79-82].

Despite these disturbances world markets for food products and agricultural trade proved to be resistant to shock caused by the COVID-19 pandemic. Agricultural trade is developing; however, the spread of COVID-19 continues to be a serious source of uncertainty affecting demand and supply of food and agricultural products [70]. Coming out of the pandemic crisis, it is necessary to control the spread of the disease while maintaining sufficient economic activity [72].

\section{Methodology and Sources of Data}

This study analyzed the capital markets of Poland and Germany. Economic and trade cooperation between these two countries is developing. According to the data of Statistics Poland (formerly the Central Statistical Office) Polish exports to Germany in 2020 amounted to 69.6 billion Euro, while imports from Germany amounted to 49.3 billion Euro. In 2020 the share of Germany in the total volume of Polish exports was $28.9 \%$. Goods from Germany accounted for 1/5 of Polish imports [83]. Similarly, as in the previous years, in 2020 Germany was also the main trade partner of Poland in the trade in agrifood products. Export of these products to Germany amounted to 8.5 billion EUR and it was by 0.8 billion EUR, i.e., 10\% higher than in 2019. The share of food products in the Polish exports to Germany in 2020 amounted to over 12\%, while in the volume of imports from Germany it was almost 9\% [84]. Cooperation on the capital market is also developing. Almost 1400 German enterprises are operating in Poland and in 2019 their total volume of trade was 89 billion Euro [85]. An important role in the cooperation between Poland and Germany is played by companies in the food sector from both countries. This study determined the effect of shock caused by the coronavirus pandemic and restrictions imposed by individual countries on the capital markets of the analyzed countries. The Thomson Reuters database was the source of data for market analyses. Abnormal rates of return from shares of 24 Polish companies and 23 German companies from the food sector 
were calculated. All of these companies of the food sector are available in the Thomson Reuters database.

Polish companies are listed on the Warsaw Stock Exchange, while German companies are listed primarily on the Frankfurt stock exchange, as well as other stock exchanges in Germany. Abnormal rates of return from shares may be treated as the response of the market to the outbreak of the pandemic. Among the analyzed Polish companies sixteen were operating in the sector of food production, while eight were from the alcoholic and non-alcoholic beverages sector. Eight German companies were operating in the food production sector and fifteen were from the alcoholic and non-alcoholic beverages. Calculations were also conducted using two stock exchange indexes from the Polish stock exchange, i.e., WIG and WIG-food. The WIG index covers all companies listed on the GPW Main Market, which meet basic criteria of participation in indexes, while the WIGfood index is a sector index, which comprises companies participating in the WIG index and at the same time classified to the food products sector. The German capital market was analyzed based on the DAX and DAX Food \& Beverages indexes. DAX is the most important German stock market index. It shows changes in the value of shares of thirty largest joint stock corporations in terms of their capitalization and turnover. The DAX Food \& Beverages index covers companies from the sector of food and beverage production.

In order to realize the aim of the study firstly actual logarithmic rates of return were calculated for individual values for the period of 510 days preceding the period when the first confirmed coronavirus case was detected in Poland. Although the first coronavirus case was reported in Germany over a month earlier, in February the response of the economies and capital markets to the pandemic were not significant, thus it seems that 4 March 2020, i.e., detection of the first COVID-19 infection in Poland, may also be included in the analysis of the German market. This also ensures a greater comparability of data in this comparative analysis of the two countries.

$$
R_{j t}=\ln \left(\frac{P_{t}}{P_{t-1}}\right)
$$

where $P_{t}$ is the price of an item on day $t$, and $P_{t-1}$ is the price of this item on the preceding day.

Next, assuming the mean adjusted model normal rates of return were used, applying the nomenclature and methodology proposed by Neumann [86], Lewandowski [87], Szyszko [88], Ebneth and Theuvsen [89]. Normal rates of return reflect rates of return expected by investors in a situation when no extraordinary events take place, such as an outbreak of a pandemic and restrictions imposed by the governments.

In the next stage means of logarithmic rates of return were calculated for individual items for the period preceding day zero, i.e., the first confirmed coronavirus case in Poland.

$$
\hat{R}_{j}=\frac{1}{510} \times \sum_{t=-510}^{t=0} R_{j t}
$$

$\hat{R}_{j}$-mean logarithmic rate of return of $j$-th item in the period of 510 days preceding day zero.

In the third step abnormal rates of return were calculated, both for each type of shares and for each day. They were calculated as the difference between the rate of return actually observed on a given day and the normal rate of return.

$$
r_{j t}=R_{j t}-\hat{R}_{j}
$$

where: $r_{j t}$-abnormal rate of return from share $j$ at time $t$. 
Rates of return for all the cases were calculated using the arithmetic mean.

$$
\bar{r}_{t}=\frac{\sum_{j=1}^{N} r_{j t}}{N}
$$

$\overline{r_{t}}$-mean abnormal rates of return from shares in period $t$,

$\mathrm{N}$-number of analyzed companies.

In the last step, the cumulative extraordinary rates of return were calculated. The length of the period under examination can be assumed in various ways. M. Firth [90] uses the period of $-/+40$ days in their research, while C. Loderer and H. Zimmermann [91] use the period of $-/+10$ months [86]. The following analysis takes for the period from $t=0$ to $t=+350$ were calculated, i.e., it was shown how rates of return changed for all and individual types of Polish and German companies caused by consequences of the COVID-19 pandemic in the period of 4 March 2020-7 July 2021. Cumulative abnormal rates of return were calculated as the sum of values of abnormal rates of return from the beginning to the end of the analyzed period, presented in previous equations.

$$
r_{t, \text { skumul. }}=\sum_{t=0}^{350} \overline{r_{t}}
$$

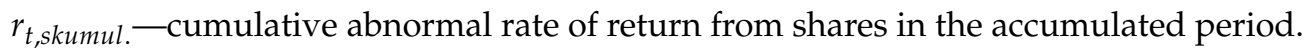
The next element in the analysis consisted in the presentation of the value of the Coronavirus (COVID-19) Pandemic, Government Response, Stringency Index [92] in the analyzed period for Poland and Germany and a comparison of changes in these values to changes in abnormal cumulative rates of return in the analyzed companies from the food sector of Poland and Germany. The index developed by researchers from the Oxford University is a tool making it possible to follow response of governments to the coronavirus pandemic. The Stringency Index [93] in a given day is calculated as the mean result of nine indicators, of which each takes the value from 0 to 100 . These indicators include school closures, workplace closures, cancelling of public events, restrictions on public meetings, lockdown of public transport, containment requirements, public information campaigns, restrictions concerning domestic travel and controls over international travel. Higher results indicate more rigorous actions. It needs to be observed here that this index records severity of the government policy. It does not determine or suggest justification or effectiveness of the response to coronavirus in a given country. A higher result does not necessarily mean that the response of a given country is "better" than those of other countries with their results being lower.

\section{Results and Discussion}

One of the methods to investigate potential effects of the pandemic for enterprises is to analyze prices of their shares $([6,10,94-96])$. In contrast to other sources of data, analyses of share prices made it possible to estimate consequences of an event with no need for long observation periods [97]. Changes in share prices result from changing expectations concerning future rates of return and risk, thus information on share prices and their variability is significant both from the point of view of managers and shareholders [98]. Analyses concerning the effect of the pandemic on capital markets were also conducted in the case of various epidemics or pandemics. They showed a negative response of the share market to the announcement of information on the spread of the epidemic. In the case of the Ebola virus epidemic in the years of 2014-2016 reports on that disease in mass media affected share prices in the USA. Results of analyses showed that information on the events related to the Ebola virus epidemic was more important for companies, which were operating geographically closer to the location, where the epidemic started. The negative effect in the form of a decrease in share prices was more marked in the case of 
small companies. Results of these analyses indicated that it is, first of all, the investor mood that influenced the investment decisions and affected share prices [99]. Analysis of the response of the Chinese stock market to COVID-19 brought similar results to those obtained in such studies on the Ebola virus. Yan [100] when investigating the response of the stock market to COVID-19 in China stated that this virus has a negative effect on rates of return from shares, although larger companies were more resilient to the shock, since they have greater resources and incur lesser losses due to the disruption of the supply chains. Conducted analyses of rates of return from shares during the COVID-19 pandemic typically did not concern the food sector, which differs from other sectors in terms of susceptibility to shock. Agricultural products are frequently difficult to handle and they are perishable, which imposes considerable limitations on geographical mobility and leads to increased transport costs [101]. Moreover, some firms in the food supply chains to a large degree rely on human labor in such operations as picking/harvesting, processing and transport. COVID-19 caused a demand shock due to the limited mobility of workers, delays in transport and limited availability of some means of production.

In the aspect of changes taking place in the food sector the authors of this study attempted to assess the effect of the pandemic on changes in rates of return from shares of companies in this sector in Poland and in Germany. In the first part of this analysis changes were compared between the WIG and DAX stock indexes with the sector indexes, i.e., WIG-food and DAX-food $\mathcal{E}$ beverage, caused by this pandemic.

When comparing abnormal cumulative rates of return from shares of companies included in the WIG i DAX indexes, we may observe rapid decreases over a short time after the first infection cases were reported. The lowest cumulative rate of return from shares in the case of DAX was recorded on the 10th day after the detection of the first infection case in Poland and it amounted to almost $-35 \%$, whereas in the case of WIG companies it was on the 6th day with the decrease of almost $-34 \%$. Up to the 57 th day in the case of DAX and the 63rd day in the case of WIG abnormal cumulative rates of return from shares were negative. After that time already over most of the period abnormal rates of return were positive. When analyzing WIG and DAX we may observe a marked correlation between abnormal cumulative rates of return from shares of companies and these indexes amounting to $96 \%$ (Pearson's correlation), although these indexes are different. The WIG index comprises many companies from the Warsaw Stock Exchange (GPW), while for DAX it is only 30 largest ones. The situation was very different in the case of companies from the food indexes. While in the initial period after the pandemic outbreak the decreases in abnormal cumulative rates of return from the food companies on stock exchanges in Poland and in Germany were comparable, in the later period this index improved markedly on the Warsaw Stock Exchange, whereas its values in the case of the food companies listed on the Frankfurt stock exchange were mostly negative (Figure 1). The marked increases in abnormal cumulative rates of return (after initial decreases) recorded for companies of the food sector in Poland were determined by several factors. Even during the coronavirus pandemic the food sector is considered by stock exchange investors as relatively stable and having good prospects for the future. It seems that consumers in Poland even more than in Germany were willing to stockpile food reserves, which contributed to increased domestic demand for food products. In the first months of the imposed social distancing retailers recorded a dramatic increase in food sales, particularly in the case of food products with longer expiry dates. It also results from the data of the National Support Centre for Agriculture (NSCA) that the growth dynamics for exports in Poland exceeded the growth rate of imports [102]. This increase resulted from the fact that due to the pandemics countries with a poorly developed agriculture but equipped with abundant financial resources wanted to develop or recreate their food reserves. This was manifested in the growing interest in Polish food on the part of such countries as e.g., Saudi Arabia, Egypt, the United Arab Emirates or Lebanon. Depreciation of the Polish currency also had a positive impact on the increase in exports. 


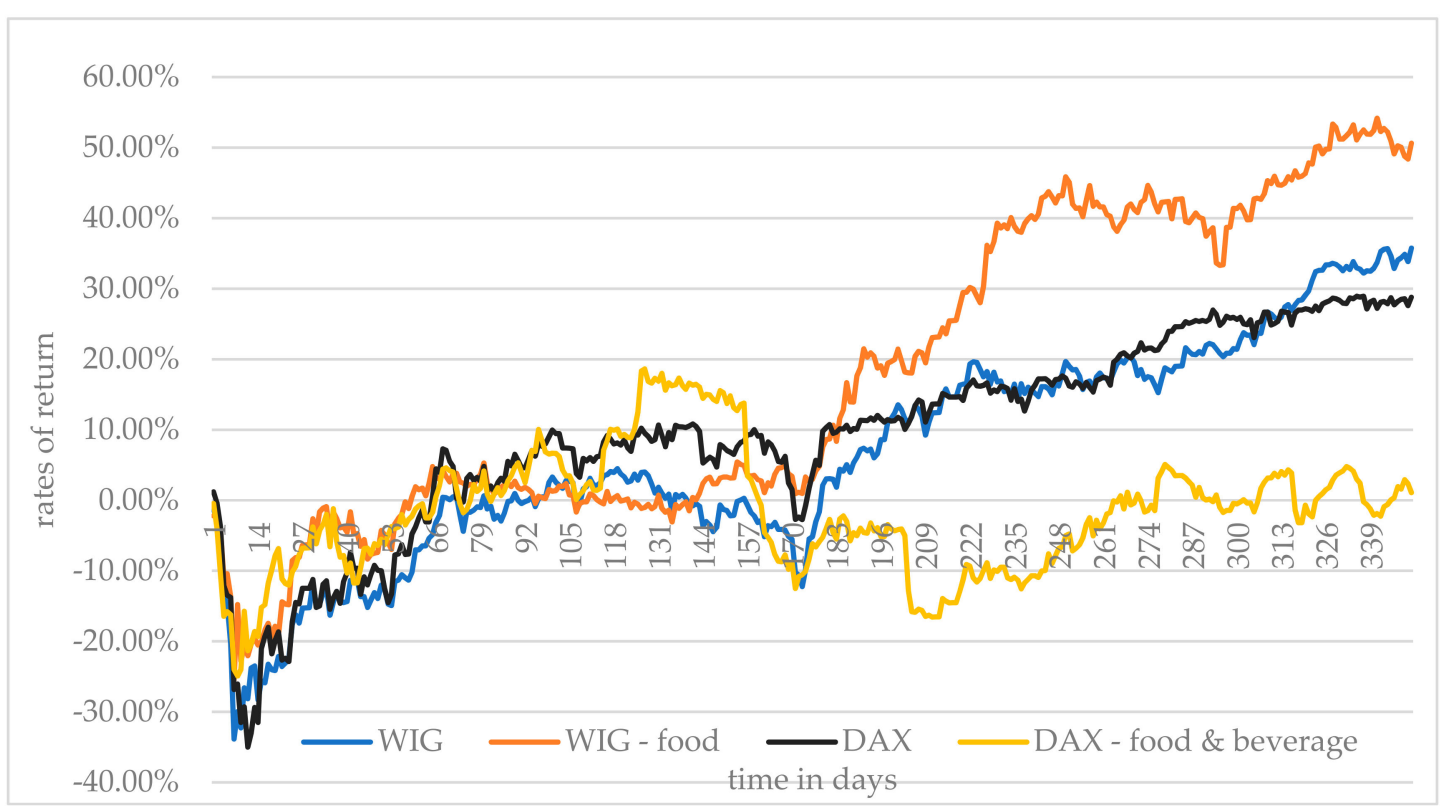

Figure 1. Mean cumulative abnormal rates of return from shares of companies included in stock market indexes purchased in the period from day 0 (reported detection of the first COVID-19 case in Poland) to day 350. Source: the authors' calculations based on data obtained from the Warsaw Stock Exchange.

However, the higher level of abnormal cumulative rates of return is evident for shares in the case of companies from the food sector compared to companies from the WIG and DAX indexes. This discrepancy may be explained using the analysis proposed by Katchova and Enlow [103]. Those authors stated that shareholders use shares of agribusiness companies to diversify their portfolios and thus to minimize risk. Also, as it was stated by Alfaro, Chari, Greenland and Schott [104], most frequently changes in share prices were caused by the response to information reaching from various sources concerning the pandemic, and to a lesser extent by actual changes in the economy and its individual sectors.

Results of analyses indicate markedly higher increases in rates of return for Polish companies from the food sector listed on GPW compared to German companies listed on several stock exchanges in Germany (Figure 2).

In the next stage of analysis for the food sector two groups of companies were distinguished, i.e., companies from the food production and the alcoholic and non-alcoholic beverages sectors. In the case of the food production companies we may observe a markedly lesser difference between abnormal cumulative rates of return from shares of Polish and German companies compared to companies from the entire food sector. In the second half of the investigated period both Polish and German companies recorded considerable increases in rates of return. In the case of German companies, abnormal rates of return were approx. 20-30\%, while in the case of Polish companies it was approx. 40-66\% (Figure 3).

In the analyzed period abnormal rates of return from shares of Polish and German companies from the sector of alcoholic and non-alcoholic beverages showed different trends. After more than 50 days of negative abnormal rates of return from shares of Polish companies in the successive days this index was positive and characterized by high increases, towards the end of the period reaching the level of more than $120 \%$. Over the entire analyzed period abnormal cumulative rates of return from German companies in the beverage sector were either negative, or their level slightly exceeded zero (Figure 4). 


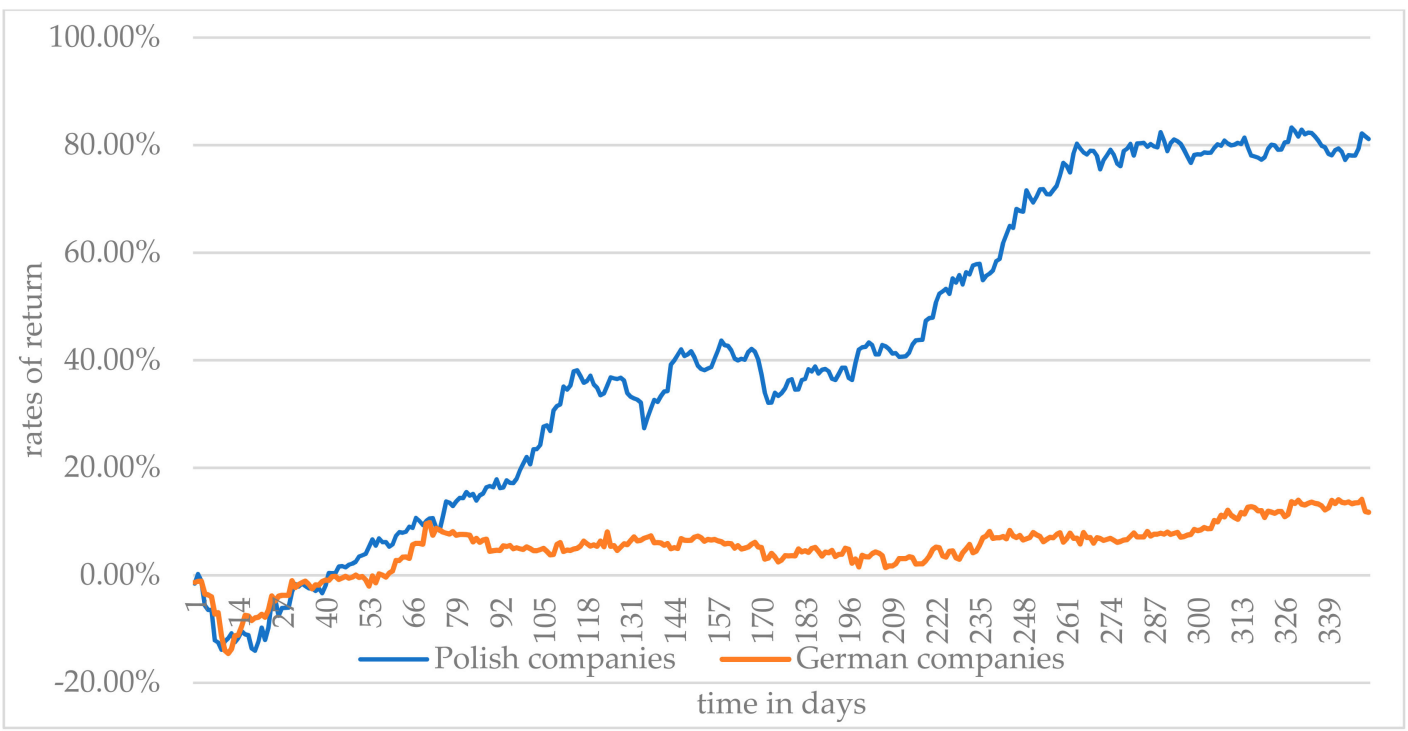

Figure 2. Mean cumulative abnormal rates of return from shares of Polish and German companies from the food sector purchased in the period from day 0 (reported detection of the first COVID-19 case in Poland) to day 350. Source: the authors' calculations based on data obtained from the Warsaw Stock Exchange.

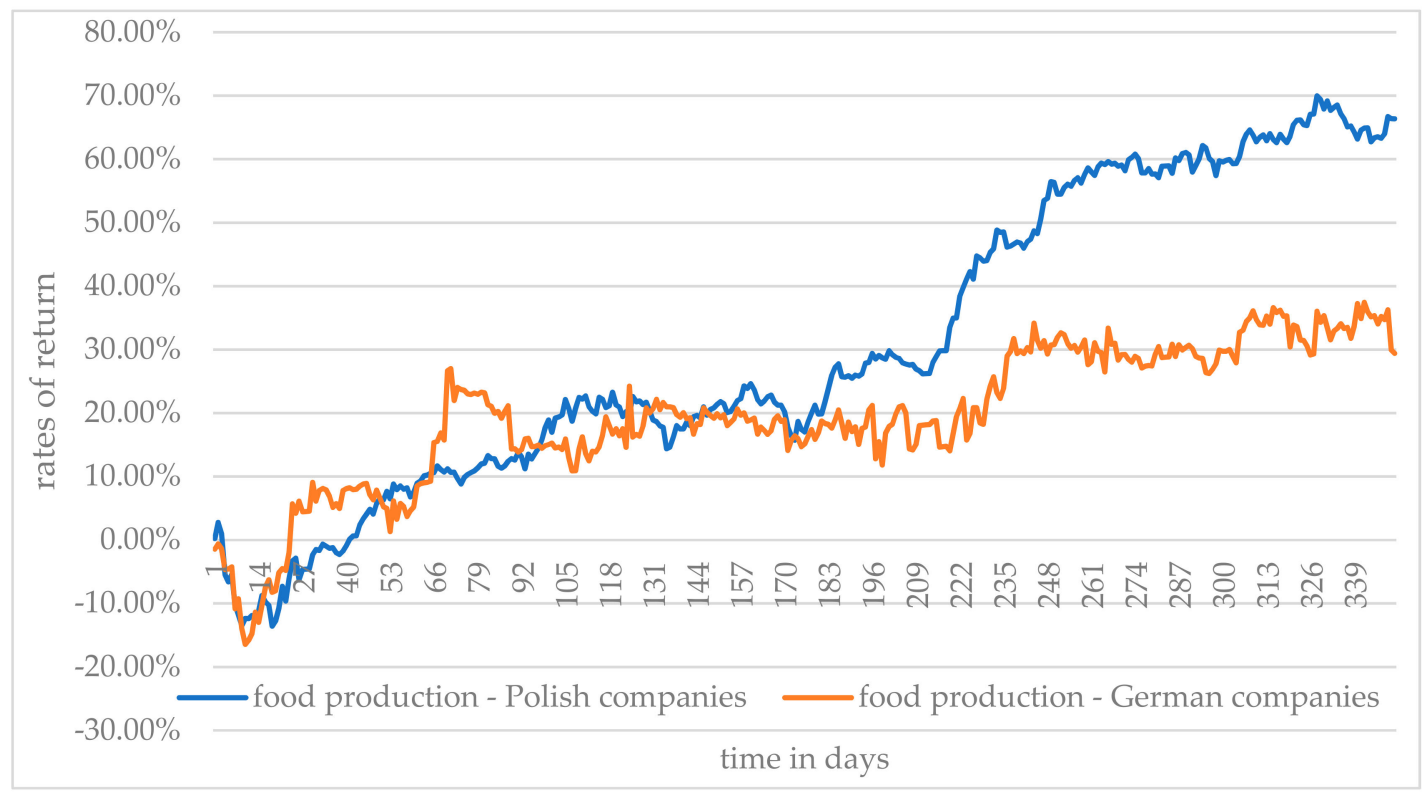

Figure 3. Mean cumulative abnormal rates of return from shares of Polish and German companies from the food production sector purchased in the period from day 0 (reported detection of the first COVID-19 case in Poland) to day 350. Source: the authors' calculations based on data obtained from the Warsaw Stock Exchange.

A hypothesis may be proposed that the level and changes in abnormal rates of return from shares of the analyzed companies to a considerable extent were determined by restrictions imposed by governments following the coronavirus pandemic outbreak. In order to determine the extent of the response of governments to the coronavirus pandemic, the Stringency Index developed by researchers from Oxford University was applied. Next the value of this index was compared in individual days of the analyzed period to the values of cumulative abnormal rates of return from shares of companies from the food sector. This analysis was conducted both for Poland and Germany. Results of this analysis for Poland indicate a lack of a marked correlation between the Stringency Index and abnormal cumulative rates of return from shares of analyzed companies (Figure 5). 


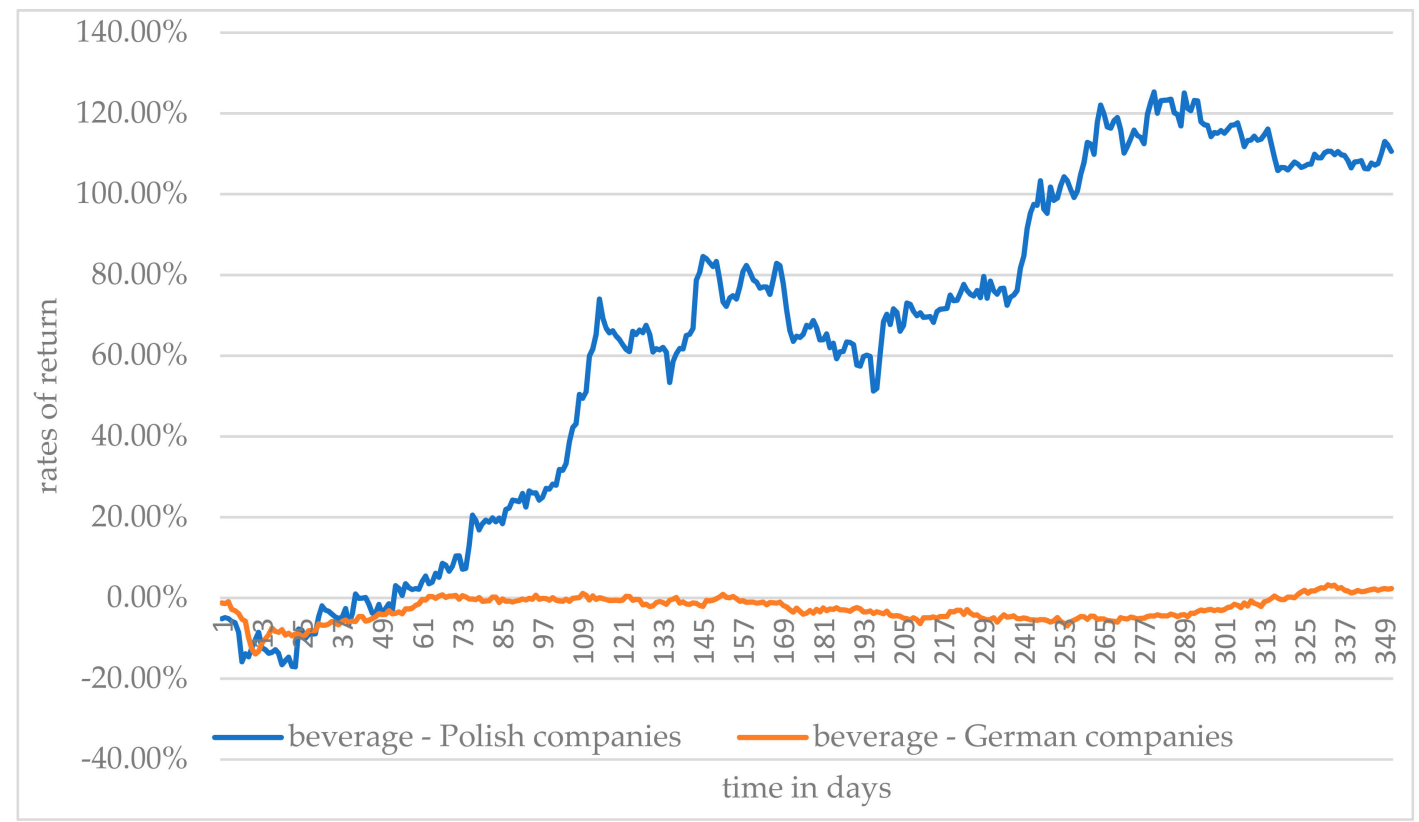

Figure 4. Mean cumulative abnormal rates of return from shares of Polish and German companies from the sector of alcoholic and non-alcoholic beverages, purchased in the period from day 0 (reported detection of the first COVID-19 case in Poland) to day 350. Source: the authors' calculations based on data obtained from the Warsaw Stock Exchange.

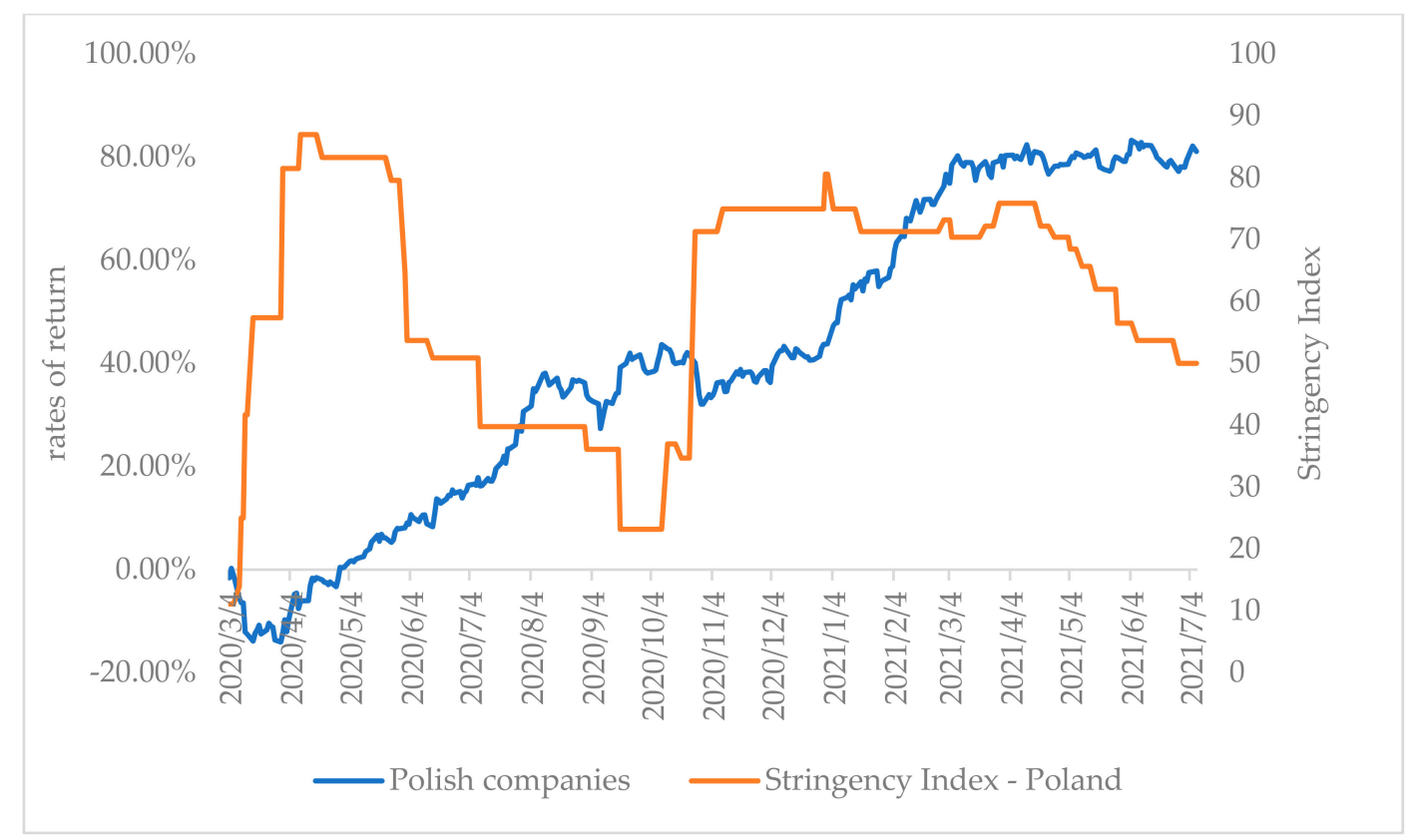

Figure 5. Mean cumulative abnormal rates of return from shares of Polish companies from the food sector compared to the Stringency Index in the period of 350 days after the pandemic outbreak. Source: the authors' calculations based on data obtained from the Warsaw Stock Exchange.

Although immediately after the pandemic outbreak and the restrictions imposed by the governments abnormal rates of return also decreased, in the later period no evident dependencies may be found between the introduced restrictions and the values of rates of return from shares. It may be assumed that changes in rates of return on the market are caused to a greater extent by behavioral aspects, concerns of investors and their irrational decisions rather than actual changes in the economy, as well as imposed restrictions. This is confirmed by analyses conducted by Alfaro, Chari, Greenland and Schott [104]. 
When comparing the value of the Stringency Index in Poland and in Germany it may be stated that the German policy towards the coronavirus pandemic was slightly more restrictive than the Polish one. Abnormal cumulative rates of return from shares of German companies from the food sector were lower than those of Polish companies. However, in the case of Germany it is also difficult to identify a definite dependency between the value of the Stringency Index and the value of rates of return from shares. This also confirms an earlier conclusion that the food sector in Poland plays a greater role than in Germany, while its position and resistance to the observed crisis were reflected in the increases in abnormal cumulative rates of return and restrictions imposed by the government to a limited extent resulted in the deterioration of the situation of this sector to a lesser extent in Poland than in Germany (Figure 6).

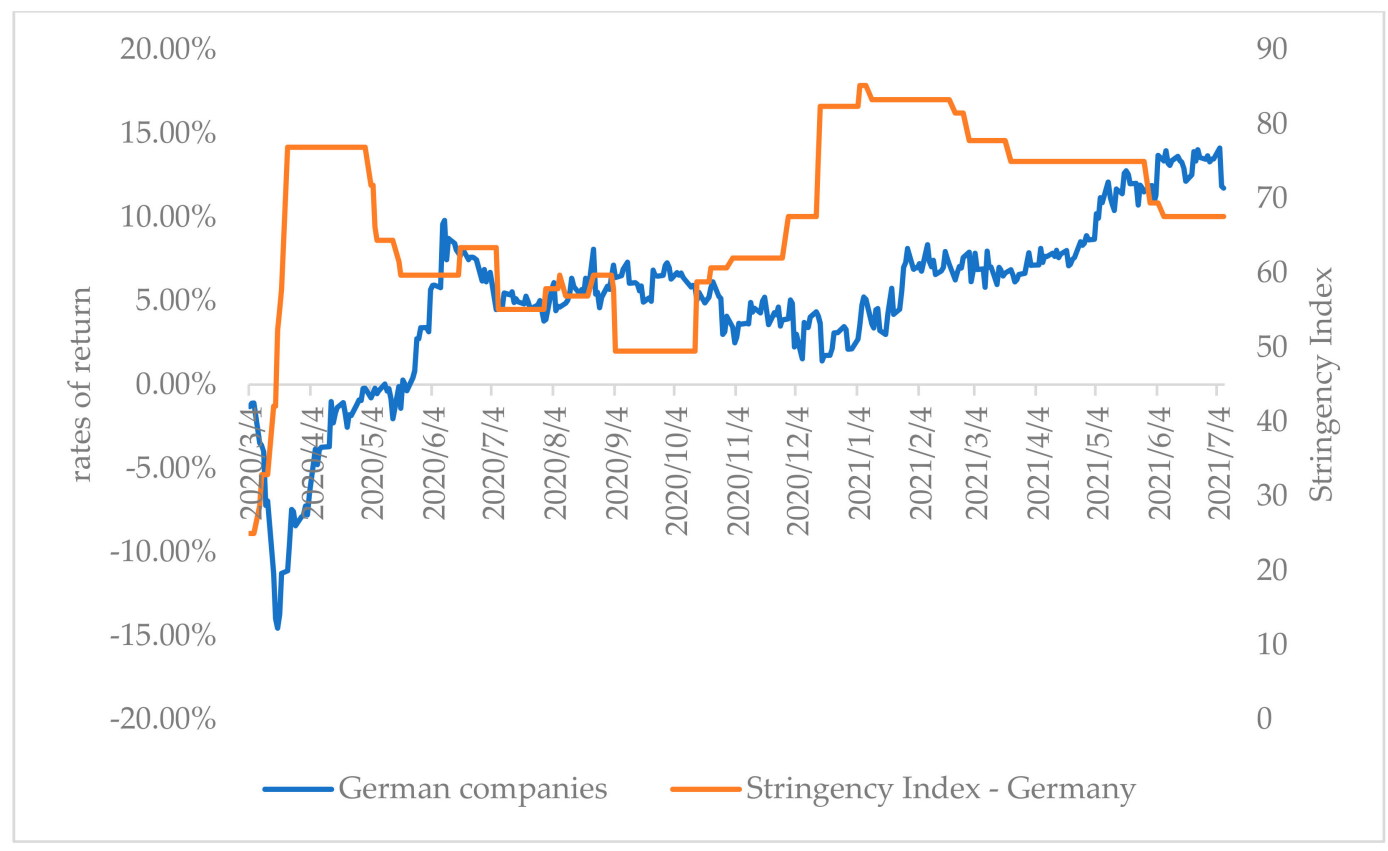

Figure 6. Mean cumulative abnormal rates of return from shares of German companies from the food sector in view of the Stringency Index in the period of 350 days after the pandemic outbreak in Poland. Source: the authors' calculations based on data obtained from the Warsaw Stock Exchange.

\section{Conclusions}

In the contemporary world economy pandemics and epidemics have been observed several times. They have caused high mortality as well as economic and financial crises. The current COVID-19 pandemic, while still lasting, is already considered to be destructive on an unprecedented scale and its consequences as well as potential effects of other diseases seem to be impossible to predict. Certain effects for the economy or the financial markets, which are brought about by violent global events such as e.g., pandemics may be determined using the black swan theory referred to economics, the theory of behavioral economics or the theory of capital market efficiency. The COVID-19 pandemic has led to the lockdown first of the Chinese economy and next the economies of many other countries. Unpredictable events caused supply-demand shocks and this led to a global crisis. However, as it is indicated by this analysis, crashes in capital markets to a greater extent were caused by behavioral aspects, concerns of investors and their irrational decisions rather than actual changes in the economy.

In this paper the main aim was to determine the effect of shock caused by the COVID19 pandemic on rates of return from shares of companies in the agri-food sector listed on stock exchanges in Poland and Germany.

Results of this analysis made it possible to draw the following conclusions: 
- following the detection of the coronavirus infection cases large decreases were recorded in cumulative rates of return from shares as a result of the pandemic both in Poland and in Germany, with greater reductions reported for companies comprising the WIG and DAX indexes compared to food companies listed within the WIG-food and $D A X$-food \& beverage indexes,

- despite differences in the WIG i DAX, abnormal cumulative rates of return from companies comprising these indexes in the analyzed period were to a considerable extent similar,

- abnormal rates of return from companies of the WIG-food index over the entire investigated period were markedly higher compared to companies from the $D A X$-food E beverage index,

- markedly greater increases in abnormal rates of return were recorded for Polish companies from the food sector listed on the Warsaw Stock Exchange in comparison to German companies listed on several stock exchanges in Germany,

- $\quad$ after more than 3 weeks of decreases in abnormal rates of return for companies from the food production sector in the following period marked increases were observed both in the case of Polish and German companies, with the increases being greater in the case of Polish companies,

- while following the initial decreases cumulative abnormal rates of return of Polish companies in the beverages sector increased considerably in the subsequent period, no increases were recorded for German companies from this sector,

- markedly greater increases in abnormal cumulative rates of return from shares of companies from the food sector in Poland than in Germany were caused by the fact that this sector plays a more important role in Poland than in Germany. Even during the coronavirus pandemic is considered by stock exchange investors on the Warsaw Stock Exchange as relatively stable and showing good prospects for the future, which was determined first of all by the increasing domestic and foreign demand for food products,

- the Stringency Index indicates that restrictions imposed by the German authorities in response to the coronavirus pandemic were slightly stricter than those introduced in Poland,

- $\quad$ there is no evident interdependence between changes in the Stringency Index in the investigated period and changes in abnormal cumulative rates of return from shares of companies from the food sector in Poland or in Germany. It may be assumed that changes in rates of return on the market were caused to a greater extent by behavioral aspects, concerns of investors and their irrational decisions rather than actual changes in the economy, as well as restrictions imposed by the governments. Investors followed their emotions, instincts and personal beliefs. In their actions, decisions and financial behavior they were not always rational and in turn their emotions and mood had a huge impact on the stock market.

This paper offers an opportunity for further studies aiming at the assessment of the effect of the COVID-19 pandemic on share markets in the agri-food sector also in other countries and worldwide, while it also suggests the advisability of further research concerning consumer behavior in crisis situations.

Author Contributions: Conceptualization, E.K. and J.K.; methodology E.K. and J.K.; writing—review and editing, E.K. and J.K.; visualization, E.K. and J.K. All authors have read and agreed to the published version of the manuscript.

Funding: This research received no external funding.

Institutional Review Board Statement: Not applicable.

Informed Consent Statement: Not applicable.

Data Availability Statement: The data presented in this study are available on request from the corresponding author. 
Conflicts of Interest: The authors declare no conflict of interest.

\section{References}

1. World Health Organization (WHO). Coronavirus Disease (COVID-19) Pandemic; WHO: Geneva, Switzerland, 2020.

2. Borsellino, V.; Kaliji, S.A.; Chimkent, E. COVID-19 Drives Consumer Behaviour and Agro-Food Markets towards Healthier and More Sustainable Patterns. Sustainability 2020, 12, 8366. [CrossRef]

3. Severo, E.A.; De Guimarães, J.; Dellarmelin, M.L. Impact of the COVID-19 pandemic on environmental awareness, sustainable consumption and social responsibility: Evidence from generations in Brazil and Portugal. J. Clean. Prod. 2020, $286,124947$. [CrossRef]

4. Hopkins, J. University \& Medicine Coronavirus Resource Center. Data Stream. 2020. Available online: https://coronavirus.jhu. edu/map.html (accessed on 27 September 2021).

5. Ortmann, R.; Pelster, M.; Wengerek, S.T. COVID-19 and Investor Behavior. Financ. Res. Lett. 2020, 37, 101717. [CrossRef]

6. Baker, S.R.; Bloom, N.; Davis, S.J.; Kost, K.; Sammon, M.; Viratyosin, T. The unprecedented stock market reaction to COVID-19. Rev. Asset Pricing Stud. 2020, 10, 742-758. [CrossRef]

7. Saleem, A.; Bárczi, J.; Sági, J. COVID-19 and Islamic Stock Index: Evidence of Market Behavior and Volatility Persistence. J. Risk Financ. Manag. 2021, 14, 389. [CrossRef]

8. Wang, F.; Zhang, R.; Ahmed, F.; Shah, S.M.M. Impact of investment behaviour on financial markets during COVID-19: A case of UK. Econ. Res. Ekon. Istraživanja 2021, 1-19. [CrossRef]

9. Kacperska, E.; Kraciuk, J. The effect of COVID-19 pandemic on the Stock market of Agri-food Companies in Poland. Eur. Res. Stud. J. 2021, XXIV, 247-290. [CrossRef]

10. Zhang, D.; Hu, M.; Ji, Q. Financial markets under the global pandemic of COVID-19. Financ. Res. Lett. 2020, 36, 101528. [CrossRef]

11. Kelley, E.K.; Tetlock, P.C. Retail short selling and stock prices. Rev. Financ. Stud. 2016, 30, 801-834. [CrossRef]

12. Garrett, T.A. Economic Effects of the 1918 Influenza Pandemic Implications for a Modern-Day Pandemic; Federal Reserve Bank of St. Louis: St. Louis, MO, USA, 2007; pp. 1-25.

13. Garrett, T.A. Pandemic Economics: The 1918 Influenza and Its Modern-Day Implications; Federal Reserve Bank of St. Louis Rev. St Louis: St. Louis, MO, USA, 2008; Volume 90, pp. 75-93.

14. Huremović, D. Pandemics throughout History. In Brief History of Pandemics. Psychiatry of Pandemics: A Mental Health Response to Infection Outbreak; Springer: Berlin/Heidelberg, Germany, 2019; pp. 7-35. [CrossRef]

15. Lee, J.W.; McKibbin, W. Estimating the Global Economic Cost of SARS in Learning from SARS: Preparing for the Next Disease Outbreak: Workshop Summary; National Academies Press: Washington, CA, USA, 2004; pp. 92-109.

16. Grzeszak, J.; Leśniewicz, F.; Śliwowski, P.; Święcicki, I. Pandenomics. Zestaw Narzędzi Fiskalnych i Monetarnych w Dobie Kryzysów; Polski Instytut Ekonomiczny: Warszawa, Poland, 2020.

17. Donadelli, M.; Ferranna, L.; Gufler, I.; Paradiso, A. Using past epidemics to estimate the macroeconomic implications of COVID-19: A bad idea! Struct. Chang. Econ. Dyn. 2021, 57, 214-224. [CrossRef]

18. Shang, Y.; Li, H.; Zhang, R. Effects of Pandemic Outbreak on Economies: Evidence from Business History Context. Front. Public Health 2021, 9, 632043. [CrossRef]

19. He, Q.; Liu, J.; Wang, S.; Yu, J. The impact of COVID-19 on stock markets. Econ. Polit. Stud. 2020, 8, 275-288. [CrossRef]

20. Hsieh, Y.-C.; Wu, T.-Z.; Liu, D.-P.; Shao, P.-L.; Chang, L.-Y.; Lu, C.-Y.; Lee, C.-Y.; Huang, F.-Y.; Huang, L.-M. Influenza Pandemics: Past, Present and Future. J. Formos. Med. Assoc. 2006, 105, 1-6. [CrossRef]

21. Barro, R.; Ursúa, J.; Weng, J. The Coronavirus and the Great Influenza Pandemic: Lessons from the "Spanish Flu" for the Coronavirus's Potential Effects on Mortality and Economic Activity. In The Coronavirus and the Great Influenza Pandemic: Lessons from the "Spanish Flu" for the Coronavirus's Potential Effects on Mortality and Economic Activity; National Bureau of Economic Research: Cambridge, MA, USA, 2020. [CrossRef]

22. Karlsson, M.; Nilsson, T.; Pichler, S. The impact of the 1918 Spanish flu epidemic on economic performance in Sweden. J. Health Econ. 2014, 36, 1-19. [CrossRef]

23. Taylor, B. The Spanish Flu and the Stock Market: The Pandemic of 1919. Global Financial Data 2020. Available online: https:/ / www.globaltrademag.com/the-spanish-flu-and-the-stock-market-the-pandemic-of-1919/ (accessed on 5 September 2021).

24. Ahmad, A.; Krumkamp, R.; Reintjes, R. Controlling SARS: A review on China's response compared with other SARS-affected countries. Trop. Med. Int. Health 2009, 14 (Suppl. S1), 36-45. [CrossRef] [PubMed]

25. Noy, I.; Shields, S. The 2003 Severe Acute Respiratory Syndrome Epidemic: A Retroactive Examination of Economic Costs. Worlds Poult. Sci. J. 2019, 591. [CrossRef]

26. Dénes, A.; Gumel, A.B. Modeling the impact of quarantine during an outbreak of Ebola virus disease. Infect. Dis. Model. 2019, 4 , 12-27. [CrossRef] [PubMed]

27. Sy, A.; Copley, A. Understanding the Economic Effects of the 2014 Ebola Outbreak in West Africa. Brookings Institution Africa in Focus Blog. 2014. Available online: http:/ / www.brookings.edu/blogs/africa-in-focus/posts/2014/10/01-ebola-outbreak-westafrica-sy-copley (accessed on 10 September 2021).

28. Dixon, S.; McDonald, S.; Roberts, J. The impact of HIV and AIDS on Africa's economic development. BMJ 2002, $324,232-234$. [CrossRef] 
29. World Bank. Global Economic Prospects. World Bank Group Flagship Report. June 2020. Available online: https://elibrary. worldbank.org/doi/abs/10.1596/978-1-4648-1553-9 (accessed on 15 September 2021).

30. World Bank. Global Economic Prospects. World Bank Group Flagship Report. June 2021. Available online: https:// openknowledge.worldbank.org/bitstream/handle/10986/35647/9781464816659.pdf (accessed on 15 September 2021).

31. Impacts of the COVID-19 Pandemic on EU Industries. European Parlament. 2021. Available online: https://www.europarl europa.eu/RegData/etudes/STUD/2021/662903/IPOL_STU(2021)662903_EN.pdf (accessed on 27 September 2021).

32. Brinca, P.; Duarte, J.B.; Castro, M.F. Is the COVID-19 Pandemic a Supply or a Demand Shock? Econ. Synop. 2020, 31, 1-3. [CrossRef]

33. Rudzewicz, A. Zaufanie w przedsiębiorstwie-znaczenie i pomiar. Zarządzanie Finansami 2017, 15, $291-304$.

34. Fama, E. Efficient Capital Markets: A Review of Theory and Empirical Work. J. Financ. 1970, 25, 383-417. [CrossRef]

35. Fama, E. Efficient Capital Markets: II. J. Financ. 1991, 46, 1575-1617. [CrossRef]

36. Tepper, R.; Urbaniak, M. Wybrane Aspekty Hipotezy o Efektywności Rynku. 2020. Available online: http://mikroekonomia.net/ system/publication_files/1113/original/24.pdf?1315295350 (accessed on 7 September 2021).

37. Shiller, R.J. From Efficient Markets Theory to Behavioral Finance. J. Econ. Perspect. 2003, 17, 83-104. [CrossRef]

38. Fromlet, H. Behavioral Finance-Theory and Practical Application: Systematic analysis of departures from the homo oeconomicus paradigm are essential for realistic financial research and analysis. Bus. Econ. 2001, 36, 63-69.

39. Guttman, I.; Kadan, O.; Kandel, E. A Rational Expectations Theory of Kinks in Financial Reporting. Account. Rev. 2006, 81, 811-848. [CrossRef]

40. Talib, A.A. The continuing behavioural modification of academics since the 1992 research assessment exercise. High. Educ. Rev. 2001, 33, 30-46.

41. Talib, N.N. The Black Swan: The Impact of the Highly Improbable; The Random House Publishing Group, Inc.: New York, NY, USA, 2007.

42. Talib, B.A.; Jani, M.F.M.; Mamat, M.N.; Zakaria, R. Impact assessment of liberalizing trade on Malaysian crude palm oil. Oil Palm Ind. Econ. J. 2007, 1, 9-17.

43. Zhang, N.; Wang, A.; Haq, N.-U.; Nosheen, S. The impact of COVID-19 shocks on the volatility of stock markets in technologically advanced countries. Econ. Res. 2021, 1-26. [CrossRef]

44. Brounen, D.; Derwall, J. The Impact of Terrorist Attacks on International Stock Markets. Eur. Financ. Manag. 2010, 16, 585-598. [CrossRef]

45. Nguyen, A.P.; Enomoto, C.E. Acts of Terrorism and Their Impacts on Stock Index Returns And Volatility: The Cases of the Karachi and Tehran Stock Exchanges. Int. Bus. Econ. Res. J. 2009, 8, 75-86. [CrossRef]

46. Arif, I.; Suleman, T. Terrorism and Stock Market Linkages: An Empirical Study from a Front-line State. Glob. Bus. Rev. 2017, 18, 365-378. [CrossRef]

47. Chen, A.H.; Siems, T.F. The effects of terrorism on global capital markets. Eur. J. Political Econ. 2004, 20, 349-366. [CrossRef]

48. Lanfear, M.G.; Lioui, A.; Siebert, M.G. Market anomalies and disaster risk: Evidence from extreme weather events. J. Financ. Markets 2018, 46, 100-477. [CrossRef]

49. Rengasamy, E. Sovereign debt crisis in the euro zone and its impact on the BRICS's stock index returns and volatility. Econ. Financ. Rev. 2012, 2, 37-46.

50. Al-Rjoub, S.A.; Azzam, H. Financial crises, stock returns and volatility in an emerging stock market: The case of Jordan. J. Econ. Stud. 2012, 39, 178-211. [CrossRef]

51. Mollick, A.V.; Assefa, T.A.U.S. Stock returns and oil prices: The tale from daily data and the 2008-2009 financial crisis. Energy Econ. 2013, 36, 1-18. [CrossRef]

52. Yin, Z.C.; Lu, H.Z.; Pan, B.X. The impact of the Sino-US trade war on China's stock market: An event-based analysis. J. Manag. 2020, 33, 18-28. [CrossRef]

53. Ma, C.; Rogers, J.H.; Zhou, S. Global economic and financial effects of 21st century pandemics and epidemics. SSRN Electron. J. 2020, 5, 56-78. [CrossRef]

54. Schwert, G.W. Stock volatility during the recent financial crisis. Eur. Financ. Manag. 2011, 17, 789-805. [CrossRef]

55. Righi, M.B.; Ceretta, P.S. Analyzing the structural behavior of volatility in the major European markets during the Greek crisis. Econ. Bull. 2011, 31, 3016-3029. [CrossRef]

56. Gil-Alana, L.A.; Monge, M. Crude oil prices and COVID-19: Persistence of the shock. Energy Res. Lett. 2020, 1, 13200. [CrossRef]

57. Liu, M.; Choo, W.; Lee, C. The Response of the Stock Market to the Announcement of Global Pandemic. Emerg. Mark. Financ. Trade 2020, 56, 3562-3577. [CrossRef]

58. Kaplanski, G.; Levy, H. Sentiment and stock prices: The case of aviation disasters. J. Financ. Econ. 2010, 95, 174-201. [CrossRef]

59. Ragin, M.A.; Halek, M. Market expectations following catastrophes: An examination of insurance broker returns. J. Risk Insur. 2016, 83, 849-876. [CrossRef]

60. Al-Rjoub, S.A.M. Business cycles, financial crises, and stock volatility in Jordan stock exchange. Soc. Sci. Electron. Publ. 2009, 31, 127-132. [CrossRef]

61. Sharif, A.; Aloui, C.; Yarovaya, L. COVID-19 pandemic, oil prices, stock market, geopolitical risk and policy uncertainty nexus in the US economy: Fresh evidence from the wavelet-based approach. Int. Rev. Financ. Anal. 2020, 70, 101496. [CrossRef] 
62. Al-Awadhi, A.M.; Alsaifi, K.; Al-Awadhi, A.; Alhammadi, S. Death and contagious infectious diseases: Impact of the COVID-19 virus on stock market returns. J. Behav. Exp. Financ. 2020, 27, 100326. [CrossRef]

63. He, P.; Sun, Y.; Zhang, Y.; Li, T. COVID-19's Impact on Stock Prices across Different Sectors-An Event Study Based on the Chinese Stock Market. Emerg. Mark. Financ. Trade 2020, 56, 2198-2212. [CrossRef]

64. Chen, M.-H.; Jang, S.; Kim, W.G. The impact of the SARS outbreak on Taiwanese hotel stock performance: An event-study approach. Int. J. Hosp. Manag. 2007, 26, 200-212. [CrossRef] [PubMed]

65. Baker, S.R.; Bloom, N.; Davis, J.; Kost, K. Policy News and Stock Market Volatility; National Bureau of Economic Research: Cambridge, MA, USA, 2019; pp. 1-54.

66. Iyke, B.N. The Disease Outbreak Channel of Exchange Rate Return Predictability: Evidence from COVID-19. Emerg. Mark. Financ. Trade 2020, 56, 2277-2297. [CrossRef]

67. Sobieralski, J.B. COVID-19 and airline employment: Insights from historical uncertainty shocks to the industry. Transp. Res. Interdiscip. Perspect. 2020, 5, 100-123. [CrossRef]

68. Guidolin, M.; Hansen, E.; Pedio, M. Cross-asset contagion in the financial crisis: A bayesian time-varying parameter approach. J. Financ. Mark. 2019, 45, 83-114. [CrossRef]

69. Saadat, S.; Rawtani, D.; Hussain, C.M. Environmental perspective of COVID-19. Sci. Total. Environ. 2020, 728, 138-870. [CrossRef]

70. FAO. COVID-19, Agricultural Markets and Trade and FAO's Response. 2020. Available online: thehttp://www.fao.org/3/nf041 en/nf041en.pdf (accessed on 27 July 2021).

71. FAO. Food Security. Policy Brief. Available online: http://www.fao.org/fileadmin/templates/faoitaly/documents/pdf/pdf_ Food_Security_Cocept_Note.pdf (accessed on 23 July 2021).

72. Norman, V.L.; Sanghi, A.; Shaharuddin, N.; Wuester, L. Recovery from the Pandemic Crisis: Balancing Short-Term Long-Term, Concerns, Research and Policy Brief. World Bank, Washington, DC. 2020. Available online: https://openknowledge.worldbank. org/handle/10986/34462 (accessed on 25 September 2021).

73. Skawińska, E.; Zalewski, R. Impact of Coronavirus COVID-19 on the Food System. Acta Sci. Polonorum. Oeconomia 2020, 19, 121-129. [CrossRef]

74. Pawlak, K. Food Security Situation of Selected Highly Developed Countries against Developing Countries. J. Agribus. Rural Dev. 2016, 40, 385-398. [CrossRef]

75. Zielińska-Chmielewska, A.; Mruk-Tomczak, D.; Wielicka-Regulska, A. Qualitative Research on Solving Difficulties in Maintaining Continuity of Food Supply Chain on the Meat Market during the COVID-19 Pandemic. Energies 2021, 14, 5634. [CrossRef]

76. Rivington, M.; King, R.; Duckett, D.; Iannetta, P.; Benton, T.G.; Burgess, P.J.; Hawes, C.; Wellesley, L.; Polhill, J.G.; Aitkenhead, M.; et al. UK Food and Nutrition Security during and after the COVID-19 Pandemic. Nutr. Bull. 2021, 46, 88-97. [CrossRef]

77. The Global Economic Outlook during the COVID-19 Pandemic: A Changed World. Available online: https://www.worldbank. org/en/news / feature/2020/06/08/the-global-economic-outlook-during-the-covid-19-pandemic-a-changed-world (accessed on 27 September 2021).

78. Zielińska-Chmielewska, A.; Olszańska, A.; Kaźmierczyk, J.; Andrianova, E.V. Advantages and Constraints of Eco-Efficiency Measures: The Case of the Polish Food Industry. Agronomy 2021, 11, 299. [CrossRef]

79. Chakrobarty, S.; Rasheduzzaman, M.; Basunia, A.K. The Impact of COVID-19 on Bangladesh's Food Security: A Review. IUP J. Supply Chain Manag. 2020, 17, 7-23.

80. Eichhorst, W.; Marx, P.; Rinne, U. Manoeuvring through the Crisis: Labour Market and Social Policies during the COVID-19 Pandemic. Intereconomics Rev. Eur. Econ. Policy 2020, 55, 375. [CrossRef]

81. Siddiqi, S.M.; Cantor, J.; Dastidar, M.G.; Beckman, R.; Richardson, A.S.; Baird, M.D.; Dubowitz, T. SNAP Participants and High Levels of Food Insecurity in the Early Stages of the COVID-19 Pandemic. Public Health Rep. 2021, 136, 457-465. [CrossRef] [PubMed]

82. Koltai, J.; Toffolutti, V.; McKee, M.; Stuckler, D. Prevalence and Changes in Food-Related Hardships by Socioeconomic and Demographic Groups during the COVID-19 Pandemic in the UK: A Longitudinal Panel Study. Lancet Reg. Health Eur. 2021, 6, 100125. [CrossRef] [PubMed]

83. Total Volume of Foreign Trade in Goods and Volume of Trade in Goods for Individual Countries in the Period of January-December 2020. Główny Urząd Statystyczny. 2021. Available online: https://stat.gov.pl/obszary-tematyczne/ceny-handel/handel/obrotytowarowe-handlu-zagranicznego-ogolem-i-wedlug-krajow-w-okresie-styczen-grudzien-2020-roku,1,101.html (accessed on 29 September 2021).

84. Polish Foreign Trade in Agri-Food Products in 2020. Ministry of Agriculture and Rural Development 2021. Available online: https: / / www.gov.pl/web/rolnictwo/polski-handel-zagraniczny-artykulami-rolno-spozywczymi-w-2020-r (accessed on 29 September 2021).

85. Polish-German Relations at the End of Angela Merkel Term. Available online: https://www.dw.com/pl/relacje-polskoniemieckie-na-koniec-rz\%C4\%85d\%C3\%B3w-angeli-merkel/a-59127843 (accessed on 28 October 2021).

86. Neuman, A. Mergers and Merger-like Business Combinations with Special Consideration of Financial Aspects; P. Haupt.: Bern, Switzerland, 1994.

87. Lewandowski, M. (Ed.) Mergers and Acquisitions in Poland against the Backdrop of Global Trends; WIG-Press: Warsaw, Poland, 2001.

88. Szyszka, A. Reakcja inwestorów na publiczne wezwania do sprzedaży akcji, Materiały Konferencyjne, Międzynarodowa Konferencja Finansów; Uniwersytet Szczeciński: Międzyzdroje, Poland, 2002; pp. 333-355. 
89. Ebneth, O.; Theuvsen, L. Internationalization and Corporate Success-Event Study Evidence on M\&As of European Brewing Groups. In Proceedings of the 15th Annual World Food and Agribusiness Symposium and Forum, Chicago, IL, USA, 23-27 August 2005.

90. Firth, M. Takeovers in New Zealand: Motives, stockholder returns, and executive share ownership. Pac. Basin Financ. J. 1997, 5, 419-440. [CrossRef]

91. Loderer, C.; Zimmermann, H. Stock offerings in a different institutional setting: The Swiss case, 1973-1983. J. Bank. Financ. 1988, 12, 353-378. [CrossRef]

92. COVID-19: Stringency Index. 2021. Available online: https:/ / ourworldindata.org/grapher/covid-stringency-index (accessed on 10 September 2021).

93. Oxford COVID-19 Government Response Stringency Index. Available online: https:/ / data.humdata.org/dataset/oxford-covid19-government-response-tracker (accessed on 13 September 2021).

94. Liu, H.; Manzoor, A.; Wang, C.; Zhang, L.; Manzoor, Z. The COVID-19 outbreak and affected countries stock markets response. Int. J. Environ. Res. Public Health 2020, 17, 2800. [CrossRef] [PubMed]

95. Ahmar, A.; Val, E. Sutte ARIMA: Short-term forecasting method, a case: COVID-19 and stock market in Spain. Sci. Total. Environ. 2020, 729, 138883. [CrossRef]

96. Ngwakwe, C.C. Effectof COVID-19 Pandemic on Global Stock Market Values. Differ. Analysis. Econ. 2020, 16, 255-269.

97. Estrella, A.; Mishkin, F.S. Predicting US recessions: Financial variables as leading indicators. Rev. Econ. Stat. 1998 80, 45-61.

98. Wang, Z.; Salin, V.; Hooker, N.H.; Leathham, D. Stock market reaction to food recalls: A GARCH application. Appl. Econ. Lett. 2002, 9, 979-987. [CrossRef]

99. Ichev, R.; Marinč, M. Stock prices and geographic proximity of information: Evidence from the Ebola outbreak. Int. Rev. Financ. Anal. 2018, 56, 153-166. [CrossRef]

100. Yan, C. COVID-19 Outbreak and Stock Prices: Evidence from China. SSRN Electron. J. 2020, 1-32. [CrossRef]

101. Rogers, R.T.; Sexton, R.J. Assessing the importance of oligopsony power in agricultural markets. Am. J. Agric. Econ. 1994, 76, 1143-1150. [CrossRef]

102. Pozytywne Tendencje w Polskim Eksporcie Artykułów Rolno-Spożywczych w 2020 r. NSCA. 2021. Available online: https:/ / www.kowr.gov.pl/biuro-prasowe/aktualnosci/pozytywne-tendencje-w-polskim-eksporcie-artykulow-rolnospozywczych-w-2020-r (accessed on 7 September 2021).

103. Katchova, A.L.; Enlow, S.J. Financial performance of publicly-traded agribusinesses. Agric. Financ. Rev. 2013, 73, 58-73. [CrossRef]

104. Alfaro, L.; Chari, A.; Greenland, A.N.; Schott, P.K. Aggregate and Firm-Level Stock Returns During Pandemics, in Real Time; National Bureau of Economic Research: Cambridge, MA, USA, 2020; Volume 10, pp. 2-24. [CrossRef] 